\title{
Opening up the politics of standard setting through Discourse Theory: The case of IFRS for SMEs
}

\begin{abstract}
Purpose: This paper investigates an element of the internal politics of standard setting by reference to the International Accounting Standards Board's [IASB] movement to the International Financial Reporting Standard for Small and Medium-Sized Entities [IFRS for $S M E s]$. We examine the politics of the IASB's expertise in technocratic governance by focusing on how the IASB defined SMEs, gave the standard a title and issued a guide for micro-entities.

Methodology: Our narrative case study focuses on central 'moments' in the development of IFRS for SMEs. We employ Laclau and Mouffe's condensation, displacement and overdetermination to illustrate embedded politics in articulating IFRS for SMEs.

Findings: We extend literature on the internal politics of standard setting, such as agenda setting, by examining the condensing of disagreements between experts and political pressures and processes into central decision moments in IFRS for SMEs. We illustrate these moments as overdetermined, manifesting in an act of displacement through the production of a micro-entity guide. This form of politics is hidden due to the IASB's attempt to protect their technocratic neutrality through fixing meaning.
\end{abstract}

Originality/value: We make three contributions. First, overdetermination through condensation and displacement illustrates the embedded nature of politics in regulatory settings, such as the IASB. Second, we provide a theoretical explanation of the IASB'S movement from listed entities to IFRS for SMEs, drawing on Laclau and Mouffe. Third, we reinforce the necessity of interrogating the internal politics of standard setting to challenge claims of technocracy.

Key words: Condensation; Displacement; Overdetermination; IASB; IFRS for SMEs; Politics. 


\section{Opening up the politics of standard setting through Discourse Theory: The case of IFRS for SMES}

\section{Introduction}

The political nature of accounting standard setting has been a focus of research for 60 years (for example, Catlett, 1960; Solomons, 1978). Much of this literature examines the role of the state in the establishment and operation of standard-setting bodies (Walker, 1987, 1992; Black, 2008), how such bodies are subject to external pressure from governments and transnational organisations (Botzem, 2012; Gallhofer and Haslam, 2007; Zeff, 2002; Perry and Nölke, 2006), and how standard setters are influenced by external lobbying (Cortese et al., 2010; Howieson, 2011; Erb and Pelger, 2015; Porter, 2014). Solomons (1978, p. 65) claimed, for example, that the "politicization" of accounting was a pathology that infected standard setting. Further research critiqued standard setting for a form of "ad-hocism" - responding to crises in accounting by issuing reactive standards (Bromwich, 1980; Horngren, 1981; Peasnell, 1982). A common thread of this study of the politics of accounting standard setting is that politics is seen as external to the technical process, something that generates healthy argument as "heated debate", or the more negative connotations associated with "extensive political lobbying".

However, within a technocratic, expert-based approach to standard-setting, this "politics" is a mere distraction from the International Accounting Standards Board's [IASB's] focus on developing "neutral" standards (IFRS Foundation [IFRSF], 2015, p. 5). Sunder (2011) argues that the IASB increasingly is given monopoly status over standard setting, being perceived as possessing technical superiority in this area. Botzem (2012) reinforces the aura of technocracy. In light of this focus on technocracy, we wish to examine the politics of expertise. This means an examination of the internal processes and practices of expertise. In their work on agenda-setting, Ram and Newberry $(2017$, p. 486) reinforce that this has received comparatively little attention:

\footnotetext{
Agenda entrance decisions involve the actions of individual board members and staff, and yet these have received little research attention ... This research reveals the power and influence wielded by key board members to overcome within-IASB opposition to the project and secure its agenda entrance.
}

We see our work as both complementary to and developmental of this study, with our associated challenge to the IASB's maintenance of a position of technocratic neutrality (Botzem, 2012) by showing how politics around expertise is embedded in the process by which the definition and title of the International Financial Reporting Standard for Small and Medium-Sized Entities [IFRS for SMES] were determined. Here, we use "politics" to refer to the internal tensions and contradictions that shape the process of accounting standard setting, and may, at the end of this process, still remain unresolved (Howieson, 2009; Botzem, 2012; Ram and Newberry, 2017). To illuminate this "shadowy underside of politics" (Devenney, 2002, p. 176), we use three political strategies from Laclau and Mouffe's (2001) Discourse Theory - condensation, displacement and overdetermination - which have scarcely 
been explored in the accounting literature. These concepts provide us with further tools to open up the "black box" of the politics of standard setting.

In 2009, the IASB published IFRS for SMEs. However, this standard applies not just to entities that had traditionally been considered to be small and medium-sized but to all entities not already subject to International Financial Reporting Standards. Our interest was piqued by the apparent contradiction between the title and the definition: the title appears to limit applicability to SMEs, but the definition suggests that the standard applies to all non-publicly accountable entities. Why did the IASB produce a standard with such a perverse title? In this paper, we show that both the title and the scope of IFRS for SMES were the outcome of a complex political process of negotiation and compromise, which belies the efforts of the IASB to present the development of IFRS for SMES as technical. We argue that examining the way in which the name and scope of the document were determined is important not only because it demonstrates the embedded politics of the standard-setting process in a new context but also because the choice of title and the determination of the scope of the document are central to the technocratic IASB's attempts to maintain and extend its hegemony over accounting standard setting. We also show that the contradictions involved in the IASB's extension of IFRS for SMEs to all entities to which full IFRS do not apply led the IASB to issue a "micro-guide" to address the concerns of smaller entities.

The IASB traditionally developed IFRS for listed entities but they extended their ambit to nonlisted entities through IFRS for SMEs (Ram and Newberry, 2013, 2017; Devi and Samujh, 2015; Di Pietra et al., 2008). As of 2018, 86 countries require or permit the use of the SME standard, with emerging economies such as South Africa, Malaysia, Brazil, Nigeria and Ghana adopting, although uptake in economically advanced countries is lower (IFRS, 2018). International financial institutions [IFIs] (such as the World Bank [WB] and the International Monetary Fund [IMF]), in their reports on individual countries, have recommended adoption (Carter and Warren, 2018a). Thus, we explore standard setting in transnational governance (Djelic and Quack, 2011; Black, 2008). The limited mainstream literature on IFRS for SMEs focuses on increasing the quality of SME financial reporting, improving user confidence and increasing access to capital for emerging economies (see Cotter et al., 2012; Pacter, 2013).

In the next section, we examine in more detail the literature that addresses the politics of accounting standard setting. Against this background, we develop our specific research questions in this section. We then set out the theoretical framework used in this paper, drawing in particular on the concepts of condensation, displacement and overdetermination that form part of Laclau and Mouffe's Discourse Theory. This is followed by a discussion of our research approach. The empirical analysis explores the politics involved in determining the scope and title of IFRS for SMEs and the development of the micro-guide. The final section of the paper identifies the contributions of the research.

\section{The Politics of Accounting Standard Setting}

Significant research examines the politics of standard setting. Much of this work explores the external politics of standard setting (see, e.g., Solomons, 1983; Walker and Robinson, 1993; 1994; Crawford et al., 2014) and includes issues such as lobbying (Klumpes, 1994; Zeff, 2002). Our focus shifts to internal politics within standard setting. This does not mean a re- 
examination of issues concerning due process (e.g. Quack 2010; Porter 2014; Camfferman and Zeff, 2015; Erb and Pelger 2015); accountability (Gallhofer and Haslam, 2007; Chiapello and Medjad, 2009; Burlaud and Colasse, 2011) or the public interest (Botzem and Quack 2009; Quack 2010; Carter and Warren, 2018b). Our focus is on the emerging stream of work that examines "the actions of individual board members and staff", which has "received little research attention" (Ram and Newberry, 2017, p. 486). In that sense, the literature on the politics of agenda setting and entrance (such as Ram and Newberry, 2017; see also Jones et al., 1994; Young, 1994; Johnson and Swieringa, 1996; Ryan, 1998) and how the IASB manage and respond to crisis (Bengtsson, 2011; Botzem, 2014) is relevant our exploration of politics in this paper.

In a simple sense, the tension we are interested in is the politics of expertise. In Botzem's (2012) evaluation of the IASB as technocratic, the IASB is powerful in maintaining a position of technocratic neutrality, but within that, there is a politics of expertise involving power and influence within the Board, between Board members and between the Board and IASB staff and others involved in standard development and setting. While other research explores why the IASB extended their ambit to non-listed entities (Camfferman and Zeff, 2015; Ram and Newberry, 2017), we are interested in the apparent tension between technocratic neutrality and the politics of expertise within the IASB in the development of IFRS for SMEs. Recent research focuses on the IASB as technocratic and examines the politics of technocracy (see Botzem, 2012, 2014; Botzem and Quack, 2009). Traditional technocracies hide behind a rhetoric of expertise, so we explore the internal discourse of expertise and the way that the IASB manage technocracy when experts agree and disagree. Researchers have begun to lift the veil of technocracy, which operates to mask the political nature of decision making (Jennings, 2011; Lövbrand and Stripple 2011; Botzem, 2012; Carter and Warren, 2018b). This is connected to Suddaby and Greenwood's (2005) argument that the analysis of debate is a window on internal tensions and contradictions (Brunsson, 1989).

We extend the understanding of the politics of technocracy by focusing on how politics manifests itself and performs through attempts to fix meaning (Laclau and Mouffe, 2001). Our research is relevant to settings beyond the IASB, and responds to calls for further study in the field of transnational governance (Black, 2008; Djelic and Quack, 2011), for work that opens up the "black box" of standard setting and the roles of power in this process (Hirsch and Lounsbury 2015) and for the exploration of internal political debates surrounding legitimacy and categorization (Durand and Maguire, 2005; Howieson, 2009; Durand and Thornton, 2018; Ram and Newberry, 2017). We focus on the politics of discursive mechanisms as developed by Laclau and Mouffe (2001) to examine this internal politics. The deconstruction of these discursive mechanisms requires us to pay attention to the internal politics of the IASB to help examine the 'power and influence' of key actors within the IASB in relation to key decision moments within the development of IFRS for SMEs.

While our work examines the internal debates central to key decision moments, IFRS for SMES is subject to research from various directions. One stream focuses on how IFRS for SMEs "fits" into particular contexts (for e.g. Quagli and Paoloni, 2012; Albu et al., 2013; Uyar and Güngörmüs, 2013). Other research examines how emerging economies were limited or excluded from the development of the IFRS for SMEs: Fearnley and Hines (2007) critique the IASB's approach for IFRS for SMEs as "top-down", while Ram and Newberry (2013) and Devi 
and Samujh (2015) illustrate the exclusion of emerging economies from the IASB's due process. These papers challenge the exclusion of interested parties and the extent to which the standard represents the views of all constituencies. Perera and Chand (2015) identify implementation issues focusing on the injustice of grouping micro-, small- and medium-sized entities due to the costs and burdens imposed upon adopting entities. The IASB attempted to address these issues by publishing a guide for micro-entities in applying IFRS for SMEs (the "micro-guide"), but this in itself can be seen as a political move by the IASB.

Thus, in the IFRS for SMEs context, limited research explores the debates internal to the IASB in developing the standard. Camfferman and Zeff (2015) provide an historical context for the development of the standard, within a contextual understanding of the IASB. A valuable paper for us is Ram and Newberry (2017)'s examination of IFRS for SMEs from an agenda entrance perspective. The way that the IFRS for SMEs project entered the IASB'S agenda defines and constrains the tensions that manifest in the definition and in how debate materialised in the daily workings of the IASB. The form of politics we are interested in is depicted in statements such as:

[The research] demonstrates the differences in power between key board members who wanted the SME project on the IASB's standard-setting agenda, and technical staff who held reservations about that. (Ram and Newberry, 2017, p. 486)

Our study is complementary to that of Ram and Newberry (2017), as we examine the politics of IFRS for SMEs once this project is on the IASB's agenda, and the politics of expertise internal to the IASB. We focus on three moments: defining SMEs; giving a title to the standard; and the subsequent publication of a micro-guide. Ram and Newberry's (2017, p. 504) agendasetting work provides the background for our contribution, as they discuss how the title of the standard was a source of tension, and how the process of defining the scope of the standard was problematic:

Even at the time of agenda entrance, the SME project title was known to be inappropriate, and its intended scope was wider than implied by the title ...

Our work is important for three reasons. First, it continues to explore the politics underlying the IASB's "technocratic" work, as governance by experts hides politics under a veil of technocracy: work to pierce that veil is therefore important. Secondly, we explore the politics involved in presenting a standard as the right answer to solve the problems of differential reporting across the globe (Ram and Newberry, 2013, 2017; Devi and Samujh, 2015). The third issue is the extension of the IASB's scope away from listed entities, which the IASB rhetorically mask through the development of IFRS for SMEs (Ram and Newberry, 2013; Devi and Samujh, 2015). To develop our focus on the embedded politics of the IASB, we examine the following questions, each of which addresses a specific "moment" in the development of IFRS for SMES:

1) How did the IASB define the term "SMEs"?

2) How did the IASB title the standard?

3) Why did the IASB develop and issue the micro-guide?

Regulatory literature tends to focus on external interactions (Black, 2002a; b; Botzem, 2012) but we shift the focus onto the embedded nature of politics for the IASB through illustrating tensions between board members, staff members, project leaders and external interests. We 
draw on Laclau and Mouffe's (2001) political strategies of condensation, displacement and overdetermination as a way of illustrating the embedded politics of standard setting. These strategies provide a framework for evaluating how the name of the standard was articulated and how defining SMEs involved attempts to fix of meaning, while the production of the micro-guide particularly illustrates displacement due to the contingencies in the standard. Our work responds to Devi and Samujh (2015) and Hopper et al.'s (2017) call for further theory-based research on standard setting.

\section{The Politics of Overdetermination}

Different definitions of the scope and titles for the SME standard were supported by various parties. Both the definition and the title provide opportunities to merge the diverse and disparate interests of interested parties. This is reinforced by Ram and Newberry's (2017) account of the agenda-setting process, and how IASB members and staff had different opinions about the need for an SME standard and concerns regarding scope. In drawing on Botzem (2012), the IASB presents their processes and debates as technical in reinforcing their technocratic expertise as the appropriate "authority" to determine accounting for SMEs and fix meaning. Laclau and Mouffe (2001) help us to deconstruct the discursive mechanisms, as the politics of attempts to fix meaning is central to their theory, and they offer tools for its deconstruction. To deconstruct the "shadowy" or hidden side of the politics of IFRS for SMEs, we draw on Laclau and Mouffe to "investigate the way social practices systematically form the identities of subjects and objects by articulating together a series of contingent signifying elements available in a discursive field" (Howarth et al., 2000, p. 7). For Laclau and Mouffe, all discourse is antagonistic. Attempts at articulation are political, as they try to cover over the antagonism and arrive at a fixed meaning (Laclau and Mouffe, 2001). These moments of fixity are "overdeterminations" in the sense that the diversity of the range of signifying elements makes it impossible for a fixed meaning to emerge without suppressing many of the signifying elements. This is a "politics of hegemony", and Discourse Theory focuses on particular points of debate (known as nodal points). These nodal points, such as what to name a standard or how to define a concept, become overdetermined due to the politics associated with fixing meaning for disparate groups with different interests.

Aspects of Discourse Theory have been drawn upon to deconstruct accounting discourse, particularly focusing on sustainability (Mouck, 1995; Spence, 2007; Brown, 2009; Tregidga et al., 2014). In particular, Spence (2007, pp. 858-859) is concerned with hegemony and the discursive functioning of politics, which provides us with a foundation to draw on:

The insights of Laclau and Mouffe in this context are of particular interest in making sense of the language and hegemonic discourse that permeates SER [social and environmental reporting] and in inferring any hegemonic character from SER. Language is viewed by Laclau and Mouffe as constitutive of social reality. That is, discourse actively shapes the world around us by providing conceptual guidance for actions, policy prescriptions, institution building etc. In this sense, Laclau and Mouffe suggest that discursive elements cannot be viewed as separate from non-discursive material elements.

Spence (2007) introduces the concept of overdetermination with respect to signifiers, but his interest is the politics of the extension of the hegemonic SER discourse and the consequent 
impact of this discourse. Like Brunsson (1989), he sees this as constituting talk with little action, thus reinforcing the status quo.

In exploring the extension of hegemony involved in SER, Spence (2007) mentioned, but did not use to any significant extent, the notions of overdetermination and nodal points. We aim to bring these notions to the centre of our analysis. To Laclau and Mouffe (2001), political discourse takes place around nodal points, which have the capacity to 'float', because the multiplicity of meanings that can be associated with nodal points has the effect of inhibiting the identification of a particular meaning. This 'floating capacity' is central to the possibility for hegemony, because signifiers can take on a range of meanings and hence 'speak to' many actors (Howarth et al., 2000, p. 9; Carter and Warren, 2018b). Thus, overdetermination (with respect to nodal points) is central to politics in the institution of 'new' social practices. We extend Spence's depiction of hegemony and overdetermination by focusing on the concepts of 'condensation' and 'displacement', which characterise the process of overdetermination. We do this by examining the politics of joining interests and positions together in nodal points, and the subsequent problematisation and deconstruction of these nodal points. Condensation explores the construction of nodal points and displacement illustrates their subsequent disruption.

Condensation operates as a type of hegemonic familiarity by narrowing political debate around a central nodal point. We see this as similar to the role of metaphor. For Laclau and Mouffe (2001), metaphor helps subjects understand something that is unfamiliar to them. This is important in connecting disparate subjects and disparate interests. Conversely, we link displacement to the Aristotelian approach to metonym (where a concept has multiple attached meanings it becomes difficult to identify a precise meaning). In our case, displacement operates post-definition and post-naming of the standard, as it is difficult for subjects to understand the precise meaning of the regulatory interventions.

INSERT FIGURE 1

Figure 1 illustrates the relevance of condensation, displacement and overdetermination to regulation, as any decision in regulation involves a range of potentialities. In the case of SMEs, for example, size, employees, users, capital needs, taxation status, profit, asset base, capitalisation, or any arbitrary construct, could define SMEs. In decision making, a regulatory body condenses available options into a "solution". In Discourse Theory, this solution - a nodal point - is an overdetermination because it attempts to articulate a wide range of options (some of which may be inconsistent with others) into a single fixed meaning. This arbitrariness becomes problematic: for example, a focus on asset base may have different impacts in different economies (a small UK entity may be a large entity comparatively in another country: see Perera and Chand, 2015). Thus, this arbitrariness begins to displace the nodal point:

... through an affirmation of the incomplete, open and politically negotiable character of every identity. This was the logic of overdetermination ... the presence of some objects in 
the others prevents any of their identities from being fixed. (Laclau and Mouffe, 2001, pp. 90-91)

Condensation and displacement help us to deconstruct this concept further. Condensation, displacement and overdetermination derive from the psychoanalysis of Freud (1900) and Lacan (1988) (Laclau and Mouffe, 2001, p. 137). Freud depicts condensation and displacement in the unconscious escapism evident in dreams, jokes and errors. In analysing dreams, condensation refers to creation at the manifest level, and is similar to metaphor. It relates to convergence, synthesis, construction and fixation that leads to signification of elements at the latent level (dream thoughts) (Lapping, 2011). The Dream of the Botanical Monograph is central for Freud's (1900, p. 386) construction of these concepts. Freud describes the dream as:

\begin{abstract}
Thus 'botanical' was a regular nodal point in the dream ... the elements 'botanical' and 'monograph' found their way into the content of the dream because they possessed copious contacts with the majority of the dream-thoughts, because, that is to say it, they constituted 'nodal points' upon which a great number of the dream-thoughts converged, and because they had several meanings in connection with the interpretation of the dream. The explanation of this fundamental fact can also be put in another way: each of the elements of the dream's content turns out to have been 'overdetermined' - to have been represented in the dream-thoughts many times over (Freud, 1900, pp. 388-389).
\end{abstract}

In overdetermination, condensation is the convergence of competing signifiers into nodal points (Spence, 2007). In our case, significant internal debate concerning the "right" definition and the "proper" title of the standard converge into the nodal points of non-publicly accountable entities and IFRS for SMEs. This converged condensation is central to articulation, illustrating how meaning emerges in an undecidable politics:

The practice of articulation, therefore, consists in the construction of nodal points which partially fix meaning; and the partial character of this fixation proceeds from the openness of the social ... (Laclau and Mouffe 2001, p. 113)

Central to Laclau and Mouffe's (2001) politics, this convergence is only a temporary fusing together of competing signifiers (Torfing, 2005; Spence, 2007), as displacement is the unravelling of this fusion. Freud $(1900$, p. 416) explains that these competing signifiers:

\footnotetext{
... constitute a connection, often a forced and far-fixed one, between the dream-content and the dream-thoughts; and if these elements were weeded out of the analysis the result would often be that the component parts of the dream-content would be left not only without overdetermination but without any satisfactory determination at all.
}

Laclau and Mouffe (2001) argue that displacement operates to unravel nodal points. Subjects striving to identify the precise meaning of a political intervention focus on what it means rather than whether the overarching regulatory problem is resolved. Therefore, displacement has the effect of taking the subjects away from the principal problem. Condensation, displacement and overdetermination highlight the way that the institution of new social practices excludes alternatives and constitutes the social as a symbolic order. Displacement occurs because of the limits of signification, as there are always antagonisms, contingencies 
and a lack in discursive structures (Laclau, 1996; Laclau and Mouffe, 2001). In our study, the unravelling constituted by displacement illuminates the IASB's failure to maintain its image of technocratic neutrality. This is illustrated by the subsequent publication of the micro-guide, which operates to challenge the primary meaning of both the definition and the title of the standard.

We suggest that the theoretical framework suggested by Figure 1 provides a rich framework for drawing out key aspects of the embedded politics of technocracy, such as in the development of IFRS for SMEs. In order to evaluate further the articulation of IFRS for SMES' discourses, we now outline the methodological approach adopted in this research.

\section{Notes on Methodology}

To study the political practices in defining and titling IFRS for SMES, we examine the internal discourses of the IASB leading up to and evident in decision making and draw out a narrative analysis through condensation, displacement and overdetermination (Czarniawska, 2000; Glynos and Howarth 2007). Within a case context (Merriam, 1998; Czarniawska, 2000), we focus on the embedded politics evident in the overdetermination of defining SMEs (condensation), the overdetermination of choosing the standard's title (condensation), and the overdetermination comprised by the subsequent publication of the micro-guide (displacement) (see Table 1 for a timeline of IFRS for SMEs). In Discourse Theory terms, each "overdetermination" involves nodal point analysis and is inherently interconnected. We employ the following research methods to understand the case.

To collect the necessary information, we draw on documents concerning IFRS for SMEs and interviews with key parties within and related to the IASB. These were collected as part of a broader study of the development of IFRS for SMEs. May (1997, pp. 157-158) suggests that documents are an important information source:

Documents, as the sedimentations of social practices, have the potential to inform and structure the decisions which people make on a daily and longer-term basis; they also constitute particular readings of social events.

Our full archive includes due process documents from the IASB and evidence from interconnected bodies, including the WB, the IMF, the European Union [EU], the United Nations Conference on Trade and Development [UNCTAD], and observer notes from meetings of the IASB: International Standard-setting Reports [IStaR]. These documents provide insight into the embedded politics of IFRS for SMES and contextualise the project to enable a greater understanding of the embedded politics. The specific documents from the archive that we refer to within this paper are listed in the bibliography. The SME agenda at the international standard-setting level predates the construction of the IASB in 2001. Chronologically, Table 1 highlights central stages and milestones within the history of the SME project. $^{1}$

\footnotetext{
${ }^{1}$ Debates concerning definition and titling occurred throughout the development of IFRS for SMEs. For further information on the history of the project, please see Camfferman and Zeff (2015) and Ram and Newberry (2017).
} 


\section{INSERT TABLE 1}

Table 1 highlights key moments in the development of IFRS for SMEs, including discussions of differential reporting by the IASC and others, the development of an agenda for the SME project in 2002, the issuing of the discussion paper in 2004, the publication of the exposure draft in 2007, the naming decision and the publication of the standard in 2009 , and the postdevelopment review process. This analysis illustrates contestations concerning different titles, different definitions of SMEs and competing understandings expressed internally and externally about the SME project. While we recognise that there were external debates on the SME project, we focus on the IASB's internal discourse as evident through examining a publicly available document archive and twenty-seven interviews. These focused interviews were conducted in 2016 with key actors involved in the development of IFRS for SMEs. ${ }^{2}$ We employed focused interviews because they encourage greater depth by allowing "interviewees to talk about the subject in terms of their own frames of reference" (May, 1997, p. 113). The focused interview technique centres on a particular question, in our case: "Why did the IASB develop IFRS for SMEs?". This encourages the exploration of emergent themes particular to each interviewee (Howarth and Torfing, 2005). Table 2 discloses the relationship of the interviewees to the IASB, listed in the order that these interviews were conducted:

\section{INSERT TABLE 2}

All interviewees, who were promised anonymity, were involved in the development of IFRS for SMEs, in various capacities: directly as board or staff members of the IASB, providing advice or feedback, or observing and researching into the IASB. The interviews lasted between 20 and 120 minutes and were digitally recorded and subsequently transcribed. The reading of documents prior to conducting the interviews gave us insight into key signifiers, tensions and conflicts. The interviews helped us to interpret the discursive "sedimentations of social practices" (May, 1997, p. 157). We read and re-read the documents and interview transcripts to identify key themes and issues concerning defining SMEs, titling the standard and publishing the micro-guide.

The paper examines the IASB's construction of the internal organisational discourse of IFRS for SMEs through a narrative analysis concerning the defining the scope of the standard, naming the standard, and the subsequent production of the micro-guide (Czarniawska, 2000; Frezatti et al., 2014). We draw on Czarniawska's (2000, p. 19) understanding of narrative work

\footnotetext{
${ }^{2}$ Because of ethics agreements with Interviewees, we are unable to disclose exact positions within the IASB. However, we interviewed Board members, staff members, and external interested parties, and incorporated a geographic representation including emerging and advanced capital economies (see Table 2). Although some interviewees are not specifically quoted in this paper, we have provided a full list to allow for cross-referencing of interviewees in any other publications based on the broader research project.
} 
to guard against linguistic reductionism and to identify the level of abstraction (Griggs and Howarth, 2006; Glynos and Howarth, 2007):

\footnotetext{
... "The voices of the field" do not speak for themselves; it is the author who makes them communicate on his or her conditions ... It is never a question of "authenticity"; it is always a question of creating an impression of authenticity, of recontextualisation that is interesting ("novel"), credible and respectful.
}

Frezatti et al. (2014, p. 439) emphasise that the "analytical task is a 'reading' of the empirical material ... and includes deconstruction, interpretation, and reconstruction". Our task involved the identification of floating signifiers and nodal points concerning the contingent issues in the development of IFRS for SMEs (for example, potential options for defining SMES or potential names for the standard) (Glynos et al., 2015). From a rhetorical viewpoint, "any [discourse] is full of potential readings" (Frezatti et al., 2014, p. 439), and this is our reading of the internal discourses of IFRS for SMEs. Each moment - defining; titling; the micro-guide - is an overdetermination that invites analysis of how these discourses and nodal points emerged. In Discourse Theory, rhetoric is constitutive of social reality and explains social phenomena (Laclau and Mouffe, 2001, p. 129). The rhetorical focus of our study is the emergence of the nodal points of definition, the title and the micro-guide, while the specifics of the discourse condensed around those nodal points illuminate the embedded politics of the IASB's technocracy.

\section{Empirical Analysis and Discussion}

\subsection{Contextualising the Empirical Analysis}

In these empirical subsections, we deconstruct various perversities in the development of IFRS for SMEs. Principally, the tension centres on the IASB's choice to define the application of the standard to non-publicly accountable entities (in effect, unlisted entities), but then chooses a title for the standard which includes the term "SMEs". Thus, while the IASB wanted to avoid quantitative characteristics concerning size or scale in their definition, they reintroduce elements of this in how they title the standard. Subsequent to the definition of the standard, the IASB produce a guide for micro-entities, which suggests that IFRS for SMES could be relevant for those entities "smaller than small". However, the guide is interconnected with the full standard. Our empirical analysis explores the debate and dispute (the politics) concerning these movements and inconsistencies within a framework of technocratic governance. Other work on IFRS for SMEs examines the perceived lack of input from emerging economies and a critical examination of the IASB's due process approach (Ram and Newberry, 2013; Devi and Samujh, 2015). We add to this work by focusing explicitly on how the standard came to be, examining central moments internal to the production of the standard including defining the scope of the standard, giving the standard a title and producing a micro-guide. Whilst we examine these movements separately, we recognise that they are interconnected movements that influence and inform each another (Czarniawska, 2000).

Table 1 provides further detail on the chronology of the development of IFRS for SMEs. Throughout the development process, different definitions, titles and discourse were drawn on. There were many different views both internal and external to the IASB throughout the 
development of the standard regarding the definition, the title and the micro-guide, so we explore these views throughout the empirics. We are aware that other bodies and contingencies were involved in this development, but we are interested in the IASB's development and decisions for the standard, not the examination of other bodies. However, when decisions are made because of external aspects we have discussed this. We focus first on the politics of defining SMEs, second on the politics of naming the standard and third on the guidance for micro-entities, all of which are interconnected and operate an implicit form of politics.

\subsection{Condensation: Defining SMEs (development)}

Bodies external to the IASB have formulated a myriad of definitions of SMEs, each of which has been debated at length and in different settings. To exemplify this, Table 3 depicts SME definitions from the ASEAN region, key trading partners and relevant IFIs.

\section{INSERT TABLE 3}

This demonstrates that regulating SMEs is complex and arbitrary. Our interviewees reflected this complexity, referring to a range of quantitative definitional features including "national legislation" (Interviewee 1), "size" (Interviewee 10), "own purpose [definitions]" (Interviewee 11), "threshold, revenue, number of employees ... private entities" (Interviewee 16), "European legislation" (Interviewee 2) and "employees" (Interviewee 4). Each competing definition of SMEs is antagonistic, but the IASB, as technocratic expert, set itself the task of articulating an appropriate regulatory framework for SME accounting. The IFRS for SMES project was complex and the IStaR observer notes show that 32 IASB meetings from the 45 across the period 2003-2009 discussed IFRS for SMEs. This is highlighted by Interviewee 3, who gave feedback to the IASB on IFRS for SMEs and was involved in the due process:

\footnotetext{
... the standard setters for years weren't even really sure what they were talking about, are they talking about companies with $\mathbf{5 0}$ employees or with $\mathbf{5 0 0}$. And I think that they got the right answer, the right answer is nothing really to do with size ... The only sensible distinction is between listed and not listed and that is where they eventually arrived, though of course the title never quite got there, so it stayed as SMEs which is unfortunately misleading.
}

Interviewee 3 depicts a definitional debate centred on size (the 50 -employee rule) and function (non-public accountability). Interviewee 3 suggests the IASB was correct in focusing on non-public accountability, which reinforces the IASB as technocratic expert. However, the IASB caused confusion by titling the standard IFRS for SMEs, implying a size-based, rather than functional definition. While there are many ways of defining SMEs (see Table 3), the IASB condensed these debates over definition by focusing on number of employees and public accountability. This condensation becomes the focus of our paper. This is not to say that other ways of defining SMEs are not important in understanding the issues relevant to SMEs and their diversity. Consequently, size versus function was central to the IASB's SME definitional discussion with the initial focus on size being redescribed later as "a political mistake" (Interviewee 11, staff member of the IASB). 


\section{Defining the Scope of Application: Size vs. Function}

IFRS for SMEs (published 9 July 2009) defines SMEs as 'entities that ... do not have public accountability'. We focus on how this definition came to be. Although the Exposure Draft [ED] (published 15 February 2007), refers to entities with no public accountability this was overshadowed by a statement that the "Board intends the IFRS for SMEs to be a stand-alone document for a typical SME with about 50 employees" (IAS Plus, 2007). The "size vs. function" debate was a significant issue commented on by almost all our interviewees. There was significant criticism of the "50 employee" discussion in comment letters on the Exposure Draft. In recognition, Interviewee 11, directly involved in developing the Exposure Draft of the standard, was a strong advocate for the project. Interviewee 11 argued that the reference to size criteria was a "political mistake":

\footnotetext{
... in the exposure draft, we made, what I would look back and say was a political mistake of saying... that this standard is intended for companies with fewer than approximately 50 employees. We said that in the basis for conclusions, but we didn't actually put that in the definition of SMEs. Well many people wrote back and said "well is that your definition, if its 51 then they've got to use full IFRS". And in the end, we said we can't sit in London and say a company with 51 employees has to use full IFRS, but 49 can use SME. We felt we're better off advising the world, think about public accountability, you decide what's publicly accountable, but our two minimum criteria are, if it's listed it publicly accountable or if it's a bank or insurance company that takes money from depositors or insure by insurance you're really depositing money ... so to me we did say 50 . We pulled that out of the final standard, because it was hard to ... we had no basis to defend it.
}

The view that a focus on 50 employees was a mistake was shared by interviewees 3, 6, 7 and 12. Interviewee 11 shows how the size criterion (50 employees) resulted in critique (displacement). However, this also illustrates an embedded critique of the IASB staff members (who were responsible for developing the ED). The sole focus on function (non-public accountability) constituted an attempt to smooth over a contingent discourse (illustrated by the size criterion). This is condensation, as the IASB's decision to not define by quantitative criteria (which dominate jurisdictional approaches to SMEs) attempts to synthesise the many definitional alternatives into the signifier "non-public accountability". From a technocratic perspective, the critical reaction to the '50 employee' construct demonstrated a narrowing effect on the standard's target audience. Consequently, to cover over the "political mistake", IFRS for SMEs focuses on non-public accountability.

The emergence of the "political mistake" signifier is revisionist because non-public accountability and 50 employees had been subject to discussion from as early as 2003 (IStaR, 2003a). The concept of "fewer than 50 employees" played a part in the IASB's discussions: IStaR observer notes $(2006$, p. 21 ) record that the standard "was aimed at companies with fewer than 50 employees", and the ED states:

In deciding on the content of the proposed IFRS for SMEs, the IASB focused on the types of transactions and other events and conditions typically encountered by SMEs with about 50 employees. For such entities, the proposed IFRS is intended to be a stand-alone document, with minimal cross-references to full IFRSs. (IASB, 2007, p. 5) 
The rhetoric of "fewer than" and "about" 50 illustrates an internal debate between IASB board members and staff, as the terms used are different. From a displacement point of view, the size criterion focused the attention of respondents, leading to limited external consultation on the "non-public accountability" definition. Interviewee 7, who was on the IFRS for SMEs working group, reflects on the implications of the size issue as a "political mistake":

\begin{abstract}
We want to develop a standard ... for around about a 50-employee firm ... I was amazed really, in hindsight that no-one ever queried that. So he was saying really, that by developing a standard for 50 would mean that you would capture the needs of medium sized companies and the very small ones, which probably it doesn't ... they were very wary, and really they had no sort of, they had very little knowledge I think of what SME was or what, I don't think they're particularly interested you know.
\end{abstract}

In this statement, Interviewee 7 illustrates the politics of expertise and questions the technocratic skillset of the IASB. The revisionism of "non-public accountability" was important to widespread adoption of the standard and from a perspective of spreading hegemony, "non-public accountability" would likely have more applicability than the narrow criterion of "50 employees".

Following the ED, IASB internal discussion concerning the "50 employees" size criterion continued. For example, the IStaR (2008b, pp. 24-25) observer notes:

There were some very sensible ideas. They were dealing with very small companies, with fewer than 50 employees. Mr McGregor ${ }^{3}$ objected that they had never said they were trying to account for micro entities.

This quote illustrates an internal tension as the size criterion of 50 employees had been a focus of the IASB, which suggests that small and micro-entities were not always in the IASB's focus. This is surprising given the IASB's focus on widespread adoption:

He [Paul Pacter $]^{4}$ thought the Board should discuss what sort of company they were aiming at. It might be that outsiders would say this was good for companies with $€ 50 \mathrm{~m}$ of turnover, and they could end up with very few companies using the standards. (IStaR, 2004, p. 7)

Because I don't believe, or sort of believe that the IASB can or should define an SME, because that's up to individual jurisdictions, it could do unlisted, non-listed, because that would be troublesome, so to my mind it was always clear that it was going to be jurisdictions who decided. (Interviewee 6, who was on the working group)

As an act of condensation, function was a safer political move because of the range of quantitative definitional features globally (Table 3). Function and definitional features are arbitrary. In an act of condensation, the IASB seeks to incorporate all these definitional debates into a standard for SMEs. Figure 2 illustrates how this act of condensation by illustrating how one arbitrary definition (focused on function) is instituted over other approaches:

\footnotetext{
${ }^{3}$ Warren McGregor was a member of the IASB during its first 10 years of operation.

4 Paul Pacter was the IASB's director of standards for SMEs, and later a member of IASB.
} 
The diagram demonstrates that defining by function operates as a floating signifier, which responds to the criticism concerned with "50 employees" and increases the political acceptability. As an act of technocracy, this has the effect of excluding alternative SME conceptions, including those focused on innovation, entrepreneurship, family firms, cooperatives or the community (a proportion of comment letters were from cooperatives). The IASB excluded cooperatives at one of its meeting:

Paul Pacter said he wanted to discuss mutuals and cooperatives. Should they be included in the standard? Warren McGregor wondered if they weren't caught by criterion 3, dealing with entities with fiduciary duties. Tricia O'Malley ${ }^{5}$ said they could have retail cooperatives that gave a return by way of discounted prices. Warren McGregor thought it was not worth bothering to include them. (IStaR, 2003b, p. 30)

This illustrates that these alternative SME forms were not within the IASB's scope, as the IASB focused on shifting unlisted entities to listed entities, improving access to capital and to maximise profit and growth (Carter and Warren, 2018a). Alternative SMEs forms fall outside this definition.

Our interest in the "political mistake" is how this illustrates an internal debate within the IASB (and how that became a public debate). The technocratic act is that the IASB condenses significant definitional debate to create a "one size fits all" standard:

We believe that the scope of the standard is currently too wide and tries to be a "one size fits all". We believe that both the user needs and types of transaction differ too much between the companies that may currently be within the scope of the standard. As a result, it will not be possible to come to an appropriate and comprehensive standard. We suggest limiting the scope (e.g. excluding small and micro companies). (CL96, 2007, p. 3) ${ }^{6}$

The IASB acknowledge the quantitative definitional features existing internationally, but seek to condense this debate through employing the floating SME signifier of non-public accountability:

P9 The IASB develops and issues a separate Standard intended to apply to the general purpose financial statements of, and other financial reporting by, entities that in many countries are referred to by a variety of terms, including small and medium-sized entities (SMEs), private entities and non-publicly accountable entities ... Many jurisdictions around the world have developed their own definitions of SMEs for a broad range of purposes including prescribing financial reporting obligations. Often those national or regional definitions include quantified criteria based on revenue, assets, employees or other factors. Frequently, the term SMEs is used to mean or to include very small entities without regard to whether they publish general purpose financial statements for external users. (IASB, 2015, p. 7)

\footnotetext{
5 Tricia O'Malley was a member of the IASB from 2001 to 2007 and subsequently a staff member.

6 If the comment letter quote is referenced 2005 this was a comment letter on the Recognition and Measurement questionnaire. If the comment letter is referenced 2007 this was a comment letter on the ED.
} 
This led to critique because arguably the IASB are attempting to make "one-size-fit-all" (Di Pietra et al., 2008). However, this does not resolve the definitional debate because each counter articulation raises new antagonisms. Di Pietra et al. (2008, p. 6) explain the unsuitability of IFRS for SMES due to the "broad definition":

Though the IASB ... explicitly states that the ED-IFRS for SMEs is suitable for micro-entities, the content of the ED seems to suggest that the IASB's focus was on larger SMEs (with more external users or stronger international orientation). The ED suggests that the financial reporting user needs for SMEs are similar or identical to those of bigger ... it has been questioned whether the IFRS for SMEs can be suitable for micro entities ...

Di Pietra et al. (2008) highlight a concern with micro-entities which was not resolved by reference to non-public accountability. The following section focuses on a connected example of embedded politics of technocracy, as the politics evident in defining the concept of SMEs is reflected in the politics of determining the title of the standard.

\subsection{Condensation: Naming the standard (development)}

Throughout the standard's development, the title changed multiple times, and the final decision of IFRS for SMEs plays an important role in subsequent confusions, as the "SME" signifier (particularly in legislation and differential reporting frameworks) traditionally invokes size criteria as definitional. The IFRSF $(2013$, p. 2 ) summarises the debate:

The title of the standard-IFRS for SMEs

The term 'SMEs' is widely recognised and used around the world...

... The IASB considered whether to use another term. Even before publishing the exposure draft in February 2007, the IASB had used the term 'non-publicly accountable entity' (NPAE) for several months during 2005. During its re-deliberations of the proposals in the exposure draft during 2008, the IASB also used both 'NPAEs' and 'private entities' for several months. Because the IASB concluded that full IFRSs are necessary for entities with public accountability, the terms 'publicly accountable entity' and 'non-publicly accountable entity' had some appeal. However, constituents argued that this term is not widely recognised, whereas 'small and medium-sized entities' and the acronym 'SMEs' are universally recognised. Also, some said that 'non-publicly accountable entities' seemed to imply, incorrectly, that the smaller entities were not publicly accountable for anything. Furthermore, the objectives of the IFRS Foundation and the IASB as set out in the Foundation's Constitution use the term 'small and medium-sized entities'...

For these reasons, the IASB decided to use 'small and medium-sized entities'. (IFRSF, 2013: 2 [emphasis added])

The IASB debated three titles: IFRS for NPAEs, IFRS for Private Entities and IFRS for SMEs. In the IASB's reasoning, the wide-recognition of the "SME" term was crucial to the final decision. The IASB rejected alternative titles by concluding that other approaches did not give due "regard" to "general purpose financial statements" or "external users". This politically delegitimises national standard setters, regulators, governments and IFIs. The IASB considered other names that reflected non-public accountability, but these were discounted as they were not as easily recognisable, despite the fact that this was the defining definitional characteristic of their regulatory intervention. We suggest that this debate (as Figure 3 
illustrates) demonstrates how the IASB masks the embedded politics around naming the standard by condensation:

\title{
INSERT FIGURE 3
}

Post-publication, the SME title created confusion and disappointment through the IASB's attempt to fix meaning (condensation), which led to competing interpretations over the standard's purpose:

... we would observe that the title of the proposed Standard is misleading. To title the Standard 'IFRS for SMEs' when it applies, in fact, not to small and medium-sized entities but rather to those entities which are not publicly accountable, is not only confusing but totally inaccurate. (CL8, 2007: 1)

This comment letter suggests that title is misleading, while CL156 (2007:1) suggests the title is inaccurate:

\begin{abstract}
Although the title of the Standard refers to SMEs, the scope is actually much broader, encompassing all non-publicly accountable entities publishing general purpose financial statements ... However, it seems that the title as currently expressed does not adequately indicate that the document should be used for these 'middle ground' entities. [Emphasis added]
\end{abstract}

Despite these criticisms, the IASB favoured international recognition. The political impact of this is that the IASB rhetorically redescribe the term SMEs (due to their definition) and employ a title and definition that best suits their political interests.

Laclau and Mouffe (2001) argue that instituting a nodal point creates antagonism and the condensation evident in defining SMEs and titling the standard begins to unravel, in a process of displacement. The initial issues with applicability, scope, the role of micro-entities and confusion between the SME title and definition all constitute the beginnings of displacement. This is evident in the debate concerning the potential usefulness of the standard, but the complexity for micro- or small-entities. This is illustrated by three quotes:

\footnotetext{
...but what we have started to hear now is ... a demand for companies that are middle tier, that are not big companies but are also not SMEs. (Interviewee 14, board member)

We believe that the SME standard will in practice be used by medium sized companies, not the very small ones as - in our opinion - the standard would be far too burdensome for the smallest companies. (CL49, 2005, p. 1)

A focus on the needs of large private entities will likely result in a set of SME standards that are broadly the same as IFRSs, with only token simplification of their recognition and measurement principles. This outcome would result in SME standards ill-suited for application by the great majority of SMEs. (CL44, 2005, p. 2)
}

These quotes suggest the standard is unsuitable for "the great majority of SMEs". However, this technocratic tension manifests following the publication of the standard, when the technocratic expertise of the IASB is maintained as IFRS for SMEs is "designed for use by small and medium-sized entities (SMEs)", which were estimated to "represent more than 95 per 
cent of all companies" (IASB, 2009, p. 1). This, we argue is a further act of condensation, but illustrates the politics of expertise and the tension between the internal discourse of unsuitability and the external presentation that this standard was suitable for 95 per cent of entities. Arguably, the IASB defined and titled the standard in such a way that they condense many entities into one standard, and 95 per cent offers a clear example of that act of condensation. We draw on this argument, following the publication of the standard, to illustrate the acts of condensation by the IASB.

\subsection{Condensation: The 95 per cent (following promulgation)}

Our analysis highlights that the "95 per cent" condensation gave rise to definitional misunderstandings and misuse of the standard. We have three examples of this: one is about how the standard should not apply to micro entities, one reflects that it should apply to micro entities but that micro entities do not understand the concept of users, and a further debate concerned the risk of subverting the IASB's technocracy through the development of standards by other bodies.

For example, Interviewee 14, an IASB board member, contends that the standard was not intended to apply to all entities and criticises jurisdictions for adopting the IASB's standard for all entities:

\footnotetext{
The other misuse of IFRS for SMEs is by genuine tiny companies, and what, in fact that's the wrong expression, it's for companies that don't need to prepare what we call ... general purpose financial statements ... and you see an awful lot of that. South Africa has fixed their system and whenever I speak about it I try and encourage others to do the same, but in many other countries, and Brazil comes to mind, they have not.
}

Interviewee 14, as a standard setter, contradicts the technocratic neutrality of the IASB, as the IASB claim that IFRS for SMEs applies to all entities that publish general purpose financial statements for external users other than those that have public accountability. Despite Interviewee 14 insisting that companies should follow South Africa and distinguish the applicability of the standard from micro-entities, inevitably the scope of the standard would include some micro-entities. The removal of any size criterion (for example, 50 employees) renders the standard potentially applicable to any entity. Take, for example, the proportional count of micro-, small- and medium entities in Indonesia: in 2010, it is reported that there were 4,838 listed entities, compared with 42,631 medium-sized entities and 573,601 small entities. These accounted for 1.15 per cent of all Indonesian businesses, with estimates of over 50 million micro businesses being recorded (Bellefleur et al., 2012). In short, if IFRS for SMEs was designed to apply to 95 per cent of Indonesian companies, then clearly that would apply to a significant proportion of Indonesian micro-entities. If a jurisdiction requires companies to publish general purpose financial statements, then that jurisdiction should not be criticised for requiring IFRS for SMEs-based reporting by companies with no public accountability. 
When asked similar questions about the scope of application of the standard, Interviewee 11 (an IASB staff member) focuses on the majority of entities having some kind of external user:

... so the link is a problem; a lack of a concept of external users of financial statements. Most little companies don't even think about the notion of external users, you know the manager says so how do we use [IFRS for SMES], but wait a minute didn't you give the bank your financial statements to ... borrow money, or did you talk to a venture capitalist, or how about your brother-in-law who bought shares in. So they are outside, but they don't accept that. The definition of an SME ... shouldn't be quantitative ... And the final one on my list, is it suitable? Is this standard suitable for micro-sized entities: to me that's an entity with fewer than 10 employees and in many countries in the world, that's $99 \%$, in most developing countries, the vast majority of companies are micros ...

Interviewee 11 confuses the matter further by referring to quantitative definitional features (i.e., 10 employees as defining micro-entities), but illustrates that IFRS for SMEs was intended to apply to micro-entities. The core question for Interviewee 11 is whether the entity has external users, illustrating the argument through a series of examples concerning borrowing. In reflecting the debates at the time of development, for example, IStaR observer notes suggest that the micro-entity issue was prominent:

Tom Jones ${ }^{7}$ urged caution, saying that there was tremendous competition from people who wanted to write standards for micros. A lot of the scope queries came from them.

(IStaR, 2008a, p. 11)

Consequently, this constitutes evidence of an internal dispute in the form of embedded politics (Suddaby and Greenwood, 2005). The contention concerning the applicability of IFRS for SMEs continues in the first comprehensive review:

Some respondents expressed concern that the IASB's primary aim in developing the IFRS for SMEs in paragraph 16 means the reporting needs of larger, more complex non-publicly accountable entities are not effectively addressed (paragraph 17(b)). However, other respondents had concerns that the IFRS for SMEs is still too complex for 'smaller' SMEs (paragraph 17(d)). Such contrasting views have been evident throughout the development of the IFRS for SMEs and show the challenge the IASB faces in determining the content of the IFRS for SMEs. (IASB, 2014, pp. 7-8)

This highlights applicability issues across the range of entities that the IASB attempt to condense within "non-public accountability", which leads to various issues:

The ED treats SMEs as a homogeneous group for which it proposes the same accounting rules with the same exemptions, assuming a common group of users, characterized by the same needs. However, for the largest number of SMEs (particularly the smaller and micro entities) the ED's 200+ pages and extensive requirements and rules may not provide an appropriate cost-benefit balance. (Di Pietra et al., 2008, p. 4; this was also a comment letter on the ED)

The IASB fuse together disparate articulations of SMEs and non-public accountability entities: the condensation is two-fold - by condensing competing SME quantitative definitions under non-public accountability they include micro-, small- and medium entities within the same standard, as illustrated in Figure 4:

\footnotetext{
7 Tom Jones was Vice-Chairman of the IASB from 2001 to 2009.
} 
The IASB technocratically condense to reinforce their expertise and cover over antagonisms and competing articulations. The IFRS for SMEs "non-public accountability" approach and the scope of applicability (micro-medium) becomes a nodal point. Politically, this movement restricts and delegitimises the emergence of alternative differential reporting frameworks by claiming that this applies to more than 95 per cent of entities. Interviewee 11 claims "[ $t$ ]he definition of an SME ... shouldn't be quantitative", while reinforcing a hegemony focused on suitability for all, comparability, increased access to capital and high-quality reporting. This illustrates the IASB's technocracy and their ability to define SMEs: from an external perspective, the IASB appears united in support of IFRS for SMEs, but the internal debate illustrates the embedded politics of the standard, as there was far from universal support within the IASB.

This is subsequently displaced as after the promulgation of the standard, there continues to be issues concerning suitability and problems with respect to defining SMEs, and giving the standard a title, because the IASB attempted to meet the needs of all in a single standard. The IASB were fixated on getting the standard "right" to reinforce technocracy, but these attempts are antagonistic. The result of this antagonism was an attempt by the IASB to rescue the project by producing a guide for micro-entities in 2013, in addition to IFRS for SMEs. We consider this an act of displacement.

\subsection{Displacement: Publishing the guidance for micro-entities}

During the first comprehensive review of IFRS for SMES, the IASB published a simplified guide for micro-entities in 2013. The repeated problematisations concerning usefulness, applicability, suitability and relevance of the standard required action by the IASB to legitimise IFRS for SMEs and maintain authority. To render IFRS for SMEs usable by micro-entities, the IASB repositioned themselves to resolve this problem by publishing Guidance for MicroEntities. The Guidance "helps [micro-entities] to identify more easily the requirements of IFRS for SMEs that are relevant to them" (IAS Plus, 2013). Interviewee 14 (board member) explains the development of the micro-guide and reflects on its take-up:

... the micro guide was created because there was, for lack of a better term, a thud factor so what had essentially happened is a lot of people were looking at our 250 page document and saying this is a really long document and we want something simpler ... the problem was that a lot of small companies don't have pension schemes, they don't have share option schemes etc, and so we thought it might be useful to simply do an extract from IFRS for SMEs, put it into a smaller book and say, if you don't have these 10 things, if you don't have a share option scheme and a pension fund and etc, then you can use this 70 page book and that might actually make your life, you know, make ... it is interesting in fact we haven't had as many people use [the micro-guide] as we thought. 
This covers over the deeper political problems with the IFRS for SMEs. Moreover, the addition further restricts the differential reporting debate, as the micro-guide appears to have resolved problematisations:

In response to requests from constituents, the IASB has developed guidance both to assist micro-sized entities currently applying the IFRS for SMEs and to make the IFRS for SMEs more accessible for those considering applying it in the future. The guidance supports the IFRS for SMEs and does not constitute a separate Standard for micro-sized entities. (IASB, 2013, p. 1)

The micro-guide is not a separate standard, but proviedes guidance for micro-entities. Figure 5 characterises the embedded nature of politics in the production of the micro-guide, by illustrating simplifying the phases of condensation from definition to the publication of IFRS for SMEs to the development of the subsequent micro-guide. This illustrates the contingency and displacement associated with the standard.

\section{INSERT FIGURE 5}

Figure 5 depicts a simplified version of the displacement. It should be read along with the complexity of condensation depicted in Figure 3. The point of displacement though is that it cuts through complexity - the production of the micro-guide seems to suggest that although there is evidence to suggest that micro-entities were part of the definitional phases of the development of the standard, this needed clarification. This is an act of displacement because although size was not supposed to be central signifier of a standard for non-public accountability, the production of a micro-guide shifts the focus back to size. The political point with respect to the micro-guide is that attempts to condense all entities into IFRS for SMES failed and was over-determined. This resulted in displacement through the micro-guide. Displacement obfuscates the political by concealing the primary identity of the dissimilar, which in our context, relates to the problematisation evident in defining and titling the standard. We illustrate this through two points:

\section{a) Claim A: Non-Public Accountability}

In the development of IFRS for SMEs, the definitional focus on 'non-public accountability' could apply to micro-entities. As Interviewee 11 (staff member) argued, "small companies have external users". Equally, the status and applicability of the standard to micro-entities was considered by the IASB during debates. There were mixed views, illustrating the embedded politics of regulatory debates, but at no point were micros explicitly excluded. This was reinforced further by the removal of any reference to 50 employees, which would exclude micro- and small-entities. Thus, the production of the micro-guide displaces these inclusive, over-determined claims in the publication of the original standard.

\section{b) Claim B: The 95 per cent}

The production of the micro-guide challenges the original claim that IFRS for SMES would apply to 95 per cent of all entities. We questioned whether the IASB had the 
necessary knowledge of SMEs to justify the 95 per cent claim. Politically, the microguide obfuscates IFRS for SMEs and operates to unpack the condensation that resulted in the original standard. The micro-guide, as an attempt to cover over contingencies, is itself partial and fails to account for other criticisms, including for example, the complexity and suitability of IFRS for these entities. For Laclau and Mouffe (2001), the displacement of the micro-guide is also displacement.

We posed three questions to help us study the politics of the IASB's standard-setting process: how did the IASB define the term "SMEs"; how did the IASB title the standard; and why did the IASB develop and issue the micro-guide? Our discussion of the empirical evidence illustrates two acts of condensation (through the non-public accountability definition and the titling of the standard) and the subsequent act of displacement through publishing the microguide. Both condensation and displacement disrupt the nodal points within IFRS for SMES, rendering it difficult to identify meaning and purpose. Through Laclau and Mouffe's (2001) concepts of condensation and displacement we have opened up the "black box" of standard setting and investigated how politics manifests itself in this process. Examining these movements demonstrates the embedded nature of politics in standard setting and lifts the veil of technocracy surrounding the IASB. We now reflect on the implications of embedded politics of standard setting.

\section{Concluding Comments and Contributions}

Previous research has examined the politics of standard setting (Solomons, 1983; Walker and Robinson, 1993; 1994; Botzem, 2012; Crawford et al., 2014; Ram and Newberry, 2017). In particular, Ram and Newberry (2017) explore the politics of agenda setting and agenda entrance, opening up an opportunity to focus on core decision moments within the development of IFRS for SMES. We add to the literature relating to the politics of standard setting by exploring the debates between the experts on the IASB, IASB staff involved in the development of the standard, and external commentators. Our exploration of the intricacies of politics in standard setting demonstrates that politics is grounded even in activities perceived to be mundane and technical. We illustrate the politics of expertise through the notion of condensation (Laclau and Mouffe, 2001). Given Botzem's (2012) explicit recognition of the politics of technocracy, this provides opportunities to study the politics of expertise within a context of claimed technocratic neutrality. We advance the work of Camfferman and Zeff (2015) and Ram and Newberry (2017) by studying the politics of expertise in core decision moments in the development of IFRS for SMEs. Our contribution exposes how tensions and issues materialised in and around core decision moments of condensation and displacement: defining the scope of the standard, naming the standard, and developing the micro-guide. Our examination, which is conducted through the lens of technocratic governance, demonstrates how moments and debates pull competing interests together behind the veil of technocratic neutrality.

We contribute further by introducing overdetermination, condensation and displacement to provide a novel theoretical framework for accounting and regulatory research that highlights contingencies inherent in standard setting. By condensing the definition and the title of IFRS 
for SMEs, the IASB "cover over" problems with respect to suitability for different entities and the inherent capital market orientation of their standards. However, all hegemonic movements construct antagonisms, as is evident in problematising the "one-size-fits-all" logic of IFRS for SMEs. The IASB attempts to "cover over" what it projects as mistakes, when these "mistakes" were, in fact, deliberate political choices by experts within the IASB. We deconstruct the logic that the IASB, as a technocratic regulator, is the body that can resolve the problems of differential reporting (Sunder, 2011; Botzem, 2012). Our deconstruction also belies the due process arguments that the IASB employs to construct their legitimacy and technocracy (Quack, 2010; Botzem, 2012; Ram and Newberry, 2013; 2017; Carter and Warren, 2018b). The IASB's reliance on due process covers over the embedded politics of technocracy and provides a framework by which the IASB, through its purported technocratic neutrality, can ignore, silence or mask certain voices.

Internal critique, as used in this paper, deconstructs the ideology of the IASB's technocracy. Drawing on the concepts of condensation and displacement expands the range of tools for the political analysis of discourse. While our analysis focuses on the politics of IFRS for SMEs, there is a need for further examination of the politics of expertise between experts, including internal disagreement and tension around the development of standards. The theoretical tools used in this paper could be employed in other debates about the IASB as well as other regulatory spaces beyond accounting. 


\section{References}

Albu, C. N., Albu, N., Pali-Pista, S. F., Gîrbină, M. M., Selimoglu, S. K., Kovács, D. M., Lukács, I., Mohl, G, Müllerová, L., Paseková, M, Arsov, A.P., Sipahi, B. and Strouhal, J. (2013), "Implementation of IFRS for SMEs in Emerging Economies: Stakeholder Perceptions in the Czech Republic, Hungary, Romania and Turkey". Journal of International Financial Management and Accounting, Vol. 24 No. 2, pp. 140-175.

Bellefleur, D., Murad, Z. and Tangkau P. (2012), "A Snapshot of Indonesian Entrepreneurship and Micro, Small, and Medium Sized Enterprise Development", USAID: United States Agency International Development, available online: https://crawford.anu.edu.au/acde/ip/pdf/lpem/2012/20120507SMERU-Dan-Thomson-Bellefleur.pdf (accessed 26 March 2018).

Bengtsson, E. (2011), Repoliticalization of accounting standard setting-The IASB, the EU and the global financial crisis. Critical Perspectives on Accounting, Vol. 22 No. 6, pp. 567-580.

Black, J. (2002a), "Critical reflections on regulation", Australian Journal of Legal Philosophy, Vol. 27, pp. 1-36.

Black, J. (2002b), “Regulatory conversations", Journal of Law and Society, Vol. 29 No. 1, pp. 163-196.

Black, J. (2008), "Constructing and contesting legitimacy and accountability in polycentric regulatory regimes", Regulation and Governance, Vol. 2 No. 2, pp. 137-164.

Botzem, S. (2012), The politics of accounting regulation: Organizing transnational standard setting in financial reporting, Edward Elgar Publishing, Cheltenham.

Botzem, S. (2014), "Transnational standard setting in accounting: Organizing expertise-based selfregulation in times of crises", Accounting, Auditing \& Accountability Journal, Vol. 27 No. 6, pp. 933955.

Botzem, S. and Quack, S. (2009), "(No) limits to Anglo-American accounting? Reconstructing the history of the International Accounting Standards Committee: a review article", Accounting, Organizations and Society, Vol. 34 No. 8, pp. 988-998.

Bromwich, M. (1980), "The possibility of partial accounting standards", Accounting Review, Vol. 55 No. 2, pp. 288-300.

Brown, J. (2009), "Democracy, sustainability and dialogic accounting technologies: Taking pluralism seriously". Critical Perspectives on Accounting, Vol. 20 No. 3, pp. 313-342.

Brunsson, N. (1989), The Organization of Hypocrisy: Talk, Decisions and Actions in Organizations, John Wiley and Sons, Chichester.

Burlaud, A. and Colasse, B. (2011), International Accounting Standardisation: is politics back?, Accounting in Europe, Vol. 8, pp. 23-47

Camfferman, K. and S. A. Zeff (2015), Aiming for Global Accounting Standards: The International Accounting Standards Board 2001-2011, Oxford University Press, Oxford.

Carter, D., and Warren, R. (2018a), "Accounting for indebtedness: geopolitics, technocracy and advanced financial capital". Innovation: The European Journal of Social Science Research, Vol. 31 No. 1, pp. 83-104.

Carter, D., and Warren, R. (2018b), "Metonyms and metaphor: the rhetorical redescription of public interest for the international accounting standards board", Critical Policy Studies, pp. 1-26. 
Catlett, G. R. (1960), Factors that influence accounting principles. Journal of Accountancy, Vol. 110 No. 4, pp. 44-50.

Chiapello, E. and Medjad, K. (2009), "An unprecedented privatisation of mandatory standard setting: The case of European accounting policy". Critical Perspectives on Accounting, Vol. 20, No. 4, pp. 448468.

Cortese, C.L., Irvine, H.J. and Kaidonis, M.A. (2010), Powerful players: How constituents captured the setting of IFRS 6, an accounting standard for the extractive industries. Accounting Forum, Vol. 34, No. 2, pp. 76-88.

Cotter, J., Tarca, A. and Wee, M. (2012), "IFRS adoption and analysts' earnings forecasts: Australian evidence", Accounting and Finance, Vol. 52 No. 2, pp. 395-419.

Crawford, L., Ferguson, J., Helliar, C. V., and Power, D. M. (2014), "Control over accounting standards within the European Union: the political controversy surrounding the adoption of IFRS 8", Critical Perspectives on Accounting, Vo. 25 No. 4, pp. 304-318.

Czarniawska, B. (2000), "The uses of narrative in organization research", GRI Report, available at: http//gupeaubguse/handle/2077/2997.

Devi, S. and Samujh, H. R. (2015), "The Political Economy of Convergence: The Case of IFRS for SMEs", Australian Accounting Review, Vol. 25 No. 2, pp. 124-138.

Devenney, M. (2002), "Critical Theory and Democracy", In A. Finlayson and J. Valentine (eds.) Politics and Post-Structuralism: An Introduction, Edinburgh University Press, Edinburgh.

Di Pietra, R., Evans, L., Chevy, J., Cisi, M., Eierle, B., Jarvis, R., and European Accounting Association's Financial Reporting Standards Committee. (2008), "Comment on the IASB's Exposure Draft 'IFRS for Small and Medium-Sized Entities"', Accounting in Europe, Vol. 5 No. 1, pp. 27-47.

Djelic, M-L, and Quack, S. (2011), Transnational governance through standard setting. The role of transnational communities in G. Morgan (ed). Twenty-First Century Capitalism. Oxford University Press, Oxford.

Durand, R., and McGuire, J. (2005). Legitimating Agencies in the Face of Selection: The Case of AACSB. Organization Studies, Vol. 26 No. 2, pp. 165-196.

Durand, R., and Thornton, P. (2018), Categorizing Institutional Logics, Institutionalizing Categories: A Review of Two Literatures. Academy of Management Annals, Vol. 12 No. 2, pp. 631-658.

Erb, C., and Pelger, C. (2015), "'Twisting words'? A study of the construction and reconstruction of reliability in financial reporting standard-setting", Accounting, Organizations and Society, Vol. 40, pp. 13-40.

Fearnley, S. and Hines, T. (2007), "How IFRS has destabilised financial reporting for UK non-listed entities", Journal of financial regulation and compliance, Vol. 15 No. 4, pp. 394-408.

Freud, S. (1900), The Interpretation of Dreams (trans. J Strachey), Penguin, London.

Frezatti, F. B., Carter, D. and Barroso, M.F.G. (2014), "Accounting without accounting: Informational proxies and the construction of organisational discourses", Accounting, Auditing \& Accountability Journal, Vol. 27 No. 3, pp. 426-464. 
Gallhofer, S. and Haslam, J. (2007), "Exploring social, political and economic dimensions of accounting in the global context: the International Accounting Standards Board and accounting disaggregation", Socio-Economic Review, Vol. 5 No. 4, pp. 633-664.

Glynos, J. and Howarth, D. (2007), Logics of critical explanation in social and political theory, Routledge, New York.

Glynos, J., Klimecki, R. and Willmott, H. (2015), "Logics in policy and practice: A critical nodal analysis of the UK banking reform process". Critical Policy Studies, Vol. 9 No. 4, pp. 393-415.

Griggs, S. and Howarth, D.R. (2006), "Metaphor, catachresis and equivalence: the rhetoric of freedom to fly in the struggle over aviation policy in the United Kingdom", Policy and Society, Vol. 25 No. 2, 2346.

Harun, H., Carter, D., Khan, H. and MacLennan, M. (2018), The Institutional Environment for Small and Medium Enterprises (SMEs) and Roles for the Accounting Profession: ASEAN Perspectives. University of Canberra, Nexus Research Centre, Canberra.

Hirsch, P., and Lounsbury, M. (2015), "Toward a More Critical and 'Powerful' Institutionalism". Journal of Management Inquiry, Vol. 24 No. 1, pp. 96-99.

Hopper, T., Lassou, P. and Soobaroyen, T. (2017), "Globalisation, Accounting and Developing Countries", Critical Perspectives on Accounting, Vol. 43, pp. 125-148.

Horngren, C. T. (1981), "Uses and limitations of a conceptual framework", Journal of Accountancy (pre1986), 151(000004), 86.

Howarth, D., Norval, A. and Stavrakakis, Y. (2000), Discourse Theory and Political Analysis: Identities, Hegemonies, and Social Change, University Press, Manchester.

Howarth, D. and Torfing. J. (2005), Discourse Theory in European Politics: Identity, Policy and Governance. Palgrave Macmillan, London.

Howieson, B. A. (2009), "Agenda formation and accounting standards setting: lessons from the standards setters", Accounting \& Finance, Vol. 49 No. 3, pp. 577-598.

Howieson, B. (2011), "GFC or KFC?: How standard setters were battered and fried", Australian Accounting Review, Vol. 21 No. 1, pp. 3-13.

Jennings, B. (2011), "Poets of the Common Good: Experts, Citizens, Public Policy." Critical Policy Studies, Vol. 5 No. 3, pp. 334-339.

Johnson, P. (1995), "Towards an epistemology for radical accounting: beyond objectivism and relativism", Critical Perspectives on Accounting, Vol. 6 No. 6, pp. 485-509.

Johnson, L. T. and Swieringa, R. J. (1996), "Anatomy of an Agenda Decision: Statement No. 115", Accounting Horizons, Vol. 10, No. 2, pp. 149-79.

Jones, S., S. F. Rahman and Wolnizer, P. (2004), "Accounting Reform in Australia: Contrasting Cases of Agenda Building", Abacus, Vol. 40, No. 3, pp. 379-404.

Klumpes, P. J. M. (1994), "The Politics of Rule Development: A Case Study of Australian Pension Fund Accounting Rule-making", Abacus, Vol. 30, No. 2, pp. 140-59.

Lacan, J. (1988), The Seminar of Jacques Lacan, Book II (trans. Sylvana Tomaselli, Jacques- Alain Miller, ed.), Cambridge University Press, Cambridge. 
Laclau E. and Mouffe C. (2001 [1985]), Hegemony and Socialist Strategy: Towards a Radical Democratic Politics, Verso, London.

Laclau, E. (1996), Emancipation(s), Verso, London.

Laclau, E. (2001), "Democracy and the Question of Power". Constellations, Vol. 8 No. 1, pp. 3-14.

Lapping, C. (2011), Psychoanalytic Theory and Sociological Method. Taylor and Francis, Abindgon.

Lövbrand, E. and Stripple, J. (2011), "Making Climate Change Governable: Accounting for Carbon as Sinks, Credits and Personal Budgets." Critical Policy Studies Vol, 5 No. 2, pp. 187-200.

May, T. (1997), Social Research: Issues, Methods, and Process, Open University Press, Buckingham.

Merriam, S. B. (1998), Qualitative research and case study applications in education. San Francisco, CA: Jossey-Bass.

Morley, J. (2016), "Internal lobbying at the IASB", Journal of Accounting and Public Policy, Vol. 35 No. 3, pp. 224-255.

Mouck, T. (1995), "Financial reporting, democracy and environmentalism: a critique of the commodification of information", Critical Perspectives on Accounting, Vol. 6 No. 6, pp. 535-553.

Pacter, P. (2013), "A Place for the IFRS for SMEs in the US?", Research in Accounting Regulation, Vol. 26 No. 2, pp. 239-241

Peasnell, K. V. (1982), "The function of a conceptual framework for corporate financial reporting", Accounting and Business Research, Vol. 12 No. 48, pp. 243-256.

Perera, D. and Chand, P. (2015), "Issues in the adoption of international financial reporting standards (IFRS) for small and medium-sized enterprises (SMES)", Advances in Accounting, Vol. 31 No. 1, pp. 165178.

Perry, J., and Nölke, A. (2006), "The political economy of international accounting standards", Review of International Political Economy, Vol. 13 No. 4, pp. 559-586.

Porter, T. (2014), Transnational Financial Regulation after the Crisis, Routledge, London.

Quack, S. (2010), "Law, expertise and legitimacy in transnational economic governance: an introduction". Socio-Economic Review, Vol. 8 No. 1, pp. 3-16.

Quagli, A., and Paoloni, P. (2012), "How is the IFRS for SME accepted in the European context? An analysis of the homogeneity among European countries, users and preparers in the European commission questionnaire". Advances in Accounting, Vol. 28 No. 1, pp. 147-156.

Ram, R., and Newberry, S. (2013). "IFRS for SMEs: The IASB'S due process", Australian Accounting Review, Vol. 23 No. 1, pp. 3-17.

Ram, R., and Newberry, S. (2017), "Agenda entrance complexity in international accounting standard setting: The case of IFRS for SMEs". Abacus, Vol. 53 No. 4, pp. 485-512

Ryan, C. (1998), "The Introduction of Accrual Reporting Policy in the Australian Public Sector: An Agenda Setting Explanation", Accounting, Auditing \& Accountability Journal, Vol. 11 No. 5, pp. 518539. 
Solomons, D. (1978), "The politicization of accounting". Journal of Accountancy (pre-1986), 146(000005), 65.

Solomons, D. (1983), "The Political Implications of Accounting and Accounting Standard Setting", Accounting and Business Research, Vol. 13, No. 50, pp. 107-118.

Spence, C. (2007), "Social and environmental reporting and hegemonic discourse". Accounting, Auditing \& Accountability Journal, Vol. 20 No. 6, pp. 855-882.

Suddaby, R., and Greenwood, R. (2005), "Rhetorical strategies of legitimacy", Administrative Science Quarterly, Vol. 50 No. 1, pp. 35-67.

Sunder, S. (2011), "IFRS monopoly: The Pied Piper of financial reporting", Accounting and Business Research, Vol. 41 No. 3, pp. 291-306.

Torfing, J. (2005), "Discourse Theory: Achievements, Arguments, and Challenges", in D. Howarth and J. Torfing, J. (eds.) Discourse Theory in European Politics, Palgrave, London.

Tregidga, H., Milne, M., and Kearins, K. (2014), "(Re) presenting 'sustainable organizations", Accounting, Organizations and Society, Vol. 39 No. 6, pp. 477-494.

Uyar, A., and Güngörmüş, A. H. (2013), "Perceptions and knowledge of accounting professionals on IFRS for SMEs: Evidence from Turkey". Research in Accounting Regulation, Vol. 25, No. 1, pp. 77-87.

Walker, R. G. (1987), "Australia's ASRB. A case study of political activity and regulatory capture", Accounting and Business Research, Vol. 17, No. 67, pp. 269-286.

Walker, R. G. (1992), "Interaction between government and the profession in the regulation of financial reporting: The Australian experience", in M. Bromwich and A. G. Hopwood (eds.) Accounting and the Law, Prentice Hall, Harlow (pp. 112-129).

Walker, R. G. and Robinson, P. (1993), "A Critical Assessment of the Literature on Political Activity and Accounting Regulation", Research in Accounting Regulation, Vol. 7, pp. 3-40.

Walker, R. G. and Robinson, P. (1994), "Competing Regulatory Agencies with Conflicting Agendas: Setting Standards for Cash Flow Reporting in Australia", Abacus, Vol. 30 No. 1, pp. 18-43.

Young, J. J. (1994), "Outlining Regulatory Space: Agenda Issues and the FASB", Accounting Organizations and Society, Vol. 19 No. 1, pp. 83-109.

Zeff, S. A. (2002), "'Political' lobbying on proposed standards: A challenge to the IASB", Accounting Horizons, Vol. 16 No. 1, pp. 43-54.

\section{Primary sources}

IASB (2009), International Accounting Standard Board Press Release: IASB published IFRS for SMEs, IASB, London.

IASB (2013), "IASB publishes Guide for Micro-sized Entities Applying the IFRS for SMEs (2009 edition)", available at: $h$ ttp://www.ifrs.org/Alerts/SME/Pages/IASB-publishes-Guide-for-Micro-sizedEntities-Applying-the-IFRS-for-SMEs-June-2013.aspx (accessed 10 October 2016).

IASB (2014), Comprehensive review SMEIG agenda paper 3 - July, IASB, London. 
IASB (2015), IFRS for SMEs 2015 standard. This official pronouncement incorporates 2015 Amendments to the IFRS for SMEs (effective 1 January 2017 with early application permitted), IASB, London.

IASB (2007), Exposure Draft: IFRS for Small and Medium Entities. London: IFRS Foundation IASB.

IAS Plus (2007), IASB invites comments on SME exposure draft, available at: https://www.iasplus.com/en/news/2007/February/news3278 (accessed 26 March 2018).

IAS Plus (2013), IASB publishes guidance for micro entities, available at:

https://www.iasplus.com/en/news/2013/06/micro-entities (accessed 26 March 2018).

IFRS (2018), Use around the world, available at: http://www.ifrs.org/use-around-the-world/use-ofifrs-standards-by-jurisdiction/\#analysis (accessed 28th March 2018).

IFRSF (2013), IFRS Foundation: Training Material for the IFRS ${ }^{\circledR}$ for SMEs including the full text of Section 1 Small and Medium- sized Entities of the International Financial Reporting Standard (IFRS) for Small and Medium-sized Entities (SMEs) issued by the International Accounting Standards Board on 9 July 2009 with extensive explanations, self-assessment questions and case studies, London, IFRS Foundation.

IFRSF (2015), Working in the Public Interest: The IFRS Foundation and the IASB, available at: http://www.ifrs.org/-/media/feature/about-us/who-we-are/working-in-the-public-interest.pdf (accessed 22 March 2018).

IStaR (2003a), Standards for Small and Medium-sized entities - IASB Board Meeting July, London.

IStaR (2003b), Standards for SMEs - IASB Board Meeting December, London.

IStaR (2004), Standards for SMEs - IASB Board Meeting April, London.

IStaR (2006), Standards for SMEs - IASB Board Meeting May, London.

IStaR (2008a), IFRS for SMEs - IASB Board Meeting March, London.

IStaR (2008b), IFRS For Private Entities - IASB Board Meeting November, London.

CL44 on RandM (2005), IFAC, UK.

CL49 on RandM (2005), Danish Institute of Certified Public Accountants, Denmark.

CL8 on ED (2007), Kingston Smith LLP, UK.

CL96 on ED (2007), The Dutch Accounting Standards Board (DASB), Netherlands.

CL156 on ED (2007), Institute of Chartered Accountants in England and Wales. 